A Systematic Review of the Career Adaptability Literature and Future Outlook

Claire S. Johnston

Department of Work and Organizational Psychology, University of Bern, Switzerland

Manuscript Accepted for Publication Journal of Career Assessment.

Author Note

This publication benefited from the support of the Swiss National Centre of Competence in Research LIVES - Overcoming vulnerability: life course perspective (http://www.lives-nccr.ch/en/page/ip7-n46), which is financed by the Swiss National Science Foundation. The authors are grateful to the Swiss National Science Foundation for its financial assistance.

Correspondence concerning this article can be sent to Claire Johnston, Department of Work and Organizational Psychology, Institute of Psychology, University of Bern, Fabrikstrasse 8, 3012 Bern, Switzerland. Email: claire.johnston@psy.unibe.ch. Tel.: +41 31 6313406

The author would like to thank Prof. Jérôme Rossier for providing comments on an earlier version of this article. 


\begin{abstract}
Researchers in the career domain have embraced the concept of career adaptability as denoted by a rapid growth in the number of published articles in recent years. Career adaptability is a psychosocial construct including both readiness and resources for successfully facing vocational tasks, occupational transitions, and unexpected challenges. To synthesize the research in this field and to suggest directions for future development, this article systematically reviews the studies on career adaptability. The 116 published pieces covered in the review include book chapters and articles including cross-sectional, longitudinal, and qualitative papers, along with intervention studies, and theoretical contributions. First the different instruments available to measure career adaptability are presented, after which the research is reviewed in the categories of adaptability resources and adapting responses. Both resources and responses contribute to positive transitions and personal functioning in teenagers through to adults. The article concludes by offering several suggestions for future research, highlighting the theoretical, practical, empirical, and methodological contributions that future work in this domain could make.

Keywords: career adaptability, adaptability resources, adaptability responses, systematic review
\end{abstract}




\section{A Systematic Review of the Career Adaptability Literature and Future Outlook}

In light of economic, social, and technological changes, the capacity to adjust, to adapt, or to display adaptability has become desirable. Popular career concepts such as protean and boundaryless careers emphasize the individual responsibility for active career management and imply that adaptability is required to be successful (e.g. Sullivan \& Baruch, 2009). In recent years, the concept of career adaptability has frequently been noted as a resource necessary for successful career development, positive responding to a number of challenges in the domains of career and work, and improved well-being (e.g. Chan \& Mai, 2015; Johnston, Maggiori, \& Rossier, 2015; Zacher 2015). But what is career adaptability and where did it come from?

\section{Theoretical Origins and Definitions of Career Adaptability}

Super and Knasel defined the term career adaptability in 1981 as an adult's "readiness to cope with changing work and working conditions" (p. 195) and although mostly pertinent for adolescents and adults, even children envision possible future selves and imagine themselves in a work role (Hartung, Porfeli, \& Vondracek, 2008). Throughout his career, Super continued to refine his career development theory and Savickas (1997) traced the theoretical progressions that led to establishment of career adaptability. Savickas (1997) proposed career adaptability as a replacement of the career maturity concept and a way to integrate the four segments of Super's life-span, life-space theory; the individual, developmental, identity, and contextual perspectives. Then, in 2005, as part of his Career Construction Theory (CCT) Savickas defined career adaptability as "a psychosocial construct that denotes an individual's readiness and resources for coping with current and imminent vocational development tasks, occupational transitions, and personal traumas" (p. 51). In the same chapter, he also refined the theoretical structure by presenting four adaptability resources, also called adapt-abilities; concern, control, curiosity, and confidence. Concern 
entails looking ahead and planning for the future, while control reflects a personal responsibility for shaping the future. Curiosity is the exploration of possible selves and various roles, and confidence is the belief that the individual can implement choices and achieve their goals (Savickas \& Porfeli, 2012).

Career adaptability researchers most frequently position their research in CCT. They locate and define career adaptability within CCT and refer to various general statements made by Savickas $(1997,2002,2005)$ as justifications for their hypotheses and research. These most often include reference to career adaptability as 1) a resource in support of its relation to positive outcomes, and a resource that leads to certain responses 2) as triggered by career transitions and therefore beneficial during expected and unexpected career changes or developmental tasks; 3) self-regulation capacities and psychosocial in nature to support career adaptability as a mediator, and 4) as a characteristic that varies across individuals suggesting career adaptability as a moderator. Along with CCT, researchers also base their research questions on other relevant theories such as self-regulation (e.g. Creed, Fallon, \& Hood, 2009) or motivational systems theory (Hirschi, 2009).

Despite the frequent mention of CCT, there are at least two alternate clear theoretical foundations in CCT on which to build career adaptability research. The first is in the form of the CCT theory propositions found in Savickas (2002) discussed later, and the second in the sequence of adaptation proposed by Savickas (2005), an avenue which I explore next.

\section{Adaptive readiness, adaptability resources, adapting responses, and adaptation}

results. A sequence of adaptation that starts with adaptive readiness, moves to adaptability resources, then to adapting responses and finally to adaptation results is outlined in CCT (Savickas, 2002, 2005) Thus, "people are more or less prepared to change, differ in their resources to manage change, demonstrate more or less change when change is needed, and as a result become more or less integrated into life roles over time" (Savickas \& Porfeli, 2012, p. 661-662). Adaptive readiness is the "personality trait of flexibility of willingness to change" 
(Savickas \& Porfeli, 2012, p. 662). Adaptability resources, concern, control, curiosity and confidence, can be drawn on to help individuals cope with current or anticipated change and are self-regulation strengths or capacities (Savickas, 1997; Savickas \& Porfeli, 2012).

Adapting responses are actual behaviours that help individuals to meet changing conditions, and finally, adaption results, are the successful outcomes of adapting (Savickas \& Porfeli, 2012). Thus, this continuum suggests that readiness, resources, responses and results should be empirically different from one another and some studies have confirmed this distinction (Hirschi, Herrmann, \& Valero, 2015; Hirschi \& Valero, 2015; Tolentino, Garcia, Restubog, Bordia, \& Tang, 2013; Tolentino et al., 2014a).

The theoretical origins of career adaptability proposed important distinctions between readiness, resources, responses, and results. Yet, this distinction is not visibly evoked in the career adaptability research. The term "career adaptability" is attached to many different concepts and constructs that are perhaps better categorized as readiness, resources, responses, or results. In particular, resources and responses are very seldom distinguished in the literature, leading to potential confusion. Nevertheless, the conceptual framework of readiness, resources, responses, and results provides a useful tool to categorize the existing literature on career adaptability. As an example of the utility of this framework, Table 1 provides a high level overview of the constructs that have been included in the career adaptability literature and how these map onto the conceptual framework of readiness, resources, responses, and results.

As will become apparent in this paper, the term "career adaptability" has been broadly applied, and thus, the aim of this paper is to systematically review the quantitative and qualitative research that has been conducted on career adaptability using various measures and to offer some recommendations for how research on this subject could be taken forward. In accomplishing this aim, this paper makes several contributions. First, it provides an overview of the existing career adaptability measures and categorizes these according to those 
that measure adaptability resources and those that measure adaptability responses. Second, this paper shows how the existing literature can be categorized according to the conceptual framework that distinguishes resources from responses. Third, based on the conceptual framework, research gaps will be identified. Fourth, to address the identified gaps, future research ideas will be given. These will show researchers and practitioners how the domain and relevance of career adaptability could be enlarged by integrating the career adaptability concept into other relevant fields such as organizational psychology.

\section{Method}

To identify published studies on career adaptability, a literature search covering peerreviewed published articles or book chapters was conducted using all the main databases including ScienceDirect, ProQuest, Springer, PsycInfo, Sage, and Taylor \& Francis Online. These databases include relevant journals in the field such as the Australian Journal of Career Development, the British Journal of Guidance and Counselling, the Career Development Quarterly, the International Journal of Educational and Vocational Guidance, the Journal of Career Assessment, the Journal of Career Development, and the Journal of Vocational Behavior. The Journals not included in these databases such as the Career Development International and the International Journal of Career Management were also searched.

The search specified that the terms "career" and "adaptability" both appeared in the titles, abstracts, or keywords. This search generated more than 500 published book chapters or articles published or available as advance online versions before the middle of September 2015. In a first round, all the articles or book chapters that included the exact term "career adaptability" in the title, abstract, or keywords or a measure of career adaptability were retained, resulting in 127 published pieces. Of these, seven pieces were excluded either because the author could not get access to the full text, or because these pieces were included in a special issue or review paper already included in the review. Another four were excluded 
because of how they measured career adaptability (see below for more details). This left 116 articles or chapters that were included in the review (marked with an * in the reference list). Studies have been conducted in a wide range of Asian and European countries, as well as America and other countries such as South Africa, Papa New Guinea, Australia, and Brazil. The research included in this review will be reviewed in the sections that follow starting with an overview of the available career adaptability measures before reviewing the literature.

\section{Literature Review}

\section{Instruments That Measure Career Adaptability}

Eight instruments that are used measure career adaptability were identified in the literature; the Career Adapt-Abilities Scale (Savickas \& Porfeli, 2012), the Career AdaptAbilities Scale Short Form (Maggiori, Rossier, \& Savickas, 2015), the Career and Work Adaptability Questionnaire (CWAQ; Nota, Ginevra, \& Soresi, 2012), the Career Maturity Inventory - Form C (CMI-Form C; Savickas \& Porfeli, 2011), the Career Adaptability Inventory (CAI; in Ferreira \&Coetzee, 2013; Ferreira, Coetzee, \& Masenge, 2013), the Student's Career Construction Inventory (SCCI; Savickas, 2009), the Career Futures Inventory (Rottinghaus, Day, \& Borgen, 2005), and the I-Adapt scale (Ployhart \& Bliese, 2006). Table 2 provides an overview of the dimensions and number of items in these measures.

These measures (and other ways of measuring career adaptability, discussed more below) represent four different approaches to the measurement of career adaptability. The first is to use measures based on the career adaptability theory as proposed by Savickas (2005). The Savickas and Porfeli (2012) Career Adapt-Abilities Scale was developed by an international research group and its development and validation in numerous countries is reported in a special issue of the Journal of Vocational Behavior (in this review, not all the individual studies are mentioned). Since then, a number of additional validation studies have been conducted in other countries using different populations (e.g. school students) including, 
for example; Turkey (Akin et al., 2014; Buyukgoze-Kavas, 2014; Öncel, 2014); Italy (preadolescents; Di Maggio, Ginevra, Laura, Ferrari, \& Soresi, 2015); German-speaking Switzerland (Johnston, Luciano, Maggiori, Ruch, \& Rossier, 2013); China (Tien, Lin, Hsieh, \& Jin, 2014); and the Philippines (Tolentino et al., 2013). The validation studies show that the conceptual structure of career adaptability replicates well in different contexts and that its construct validity can be demonstrated.

The Career Adapt-Abilities Scale - Short Form (Maggiori et al., 2015) and an adapted French version of the Career Adapt-Abilities Scale (Johnston et al., 2013b) are adaptations to the Career Adapt-Abilities Scale to encourage the applicability of the scale in varied contexts. Zacher (2015) adapted the wording of the items found in the Career Adapt-Abilities Scale to provide a daily behavioural measure of career adaptability.

Many of the other instruments (CWAQ, CMI-Form C, CAI, and SCCI), are based on the Savickas conceptualization of career adaptability and aim to measure the same or very similar dimensions as in the Career Adapt-Abilities Scale (concern, control, curiosity, and confidence) and cooperation as this was included in earlier conceptualizations. The CWAQ (Nota et al., 2012) is aimed at high school students and is a measure of adolescent's adaptability resources (concern, control, curiosity, and confidence). The Career Maturity Inventory - Form $\mathrm{C}$ is targeted at students and provides a specific measure of one developmental task, that of making an occupational or educational choice (Glavin, 2015). The CMI-Form $\mathrm{C}$ gives a total score for career choice readiness, three scale scores reflecting adaptability resources (concern, curiosity and confidence) and a score for consultation that reflects an individual's relational style in making occupational choices- and preliminary findings support the reliability and validity of this measure (Savickas \& Porfeli, 2011). The SCCI (Savickas, 2009 in Rocha 2012; 2015) measures career resources with the dimensions of concern, curiosity, confidence, control and cooperation. Finally, the CAI (Ferreira 
\&Coetzee, 2013; Ferreira et al., 2013) also measures the career adaptability resources (concern, curiosity, confidence, control and cooperation).

The second approach is to select subscales designed to measure career adaptability from other measures that also include other subscales. Here the most commonly used scale is the original Career Futures Inventory (Rottinghaus et al., 2005) that contains 3 subscales; career adaptability, career optimism, and perceived knowledge. The career adaptability subscale is intended to reflect the Savickas conceptualization of career adaptability that includes planning, self and environment exploration, and informed decision-making (Rottinghaus et al., 2005; Savickas 1997). This scale was revised in 2012 (Rottinghaus, Buelow, \& Matyja, 2012) but to the author's knowledge has not been used as a measure of career adaptability. The I-Adapt scale is a measure of an individual's adaptability and flexibility in regard to their work and social environments and includes 8 subscales (Ployhart $\&$ Bliese, 2006). One study that used the I-Adapt as a measure of career adaptability selected two subscales, work stress adaptability and uncertainty adaptability (Cotter \& Fouad, 2012) to represent an individual's ability to cope with unpredictable changes in the work life.

The third is to collect a variety of indicators such as career choice readiness, career planning, career exploration, and confidence (Hirschi, 2009) or planfulness, exploration, decision making, and self-regulation (Creed et al., 2009) based on relevant career theories.

The fourth approach includes studies in which authors have chosen their own conceptualization of career adaptability, not clearly linked to the approaches above. Ito and Brotheridge (2005) used career development activities and career resilience as measures of career adaptability but seemingly did not connect this to a clear theory, and Kenny and Bledsoe (2005) used school identification, perceptions of educational barriers, outcome expectancies, and career planning as indicators of career adaptability, labelling these as career tasks. McArdle, Waters, Briscoe, and Hall (2007) conceptualized adaptability as proactive personality and boundaryless mindset although the justification for including boundaryless 
mindset seemed to be lacking. McIlveen, Beccaeia, and Burton (2013) conceptualized career adaptability as optimism and generalized self-efficacy, but in their model, self-efficacy predicted optimism leaving some questions as to the exact conceptualization of career adaptability. While alternate approaches can stimulate discussion, these approaches need to be grounded clearly in theory, and if this is lacking, these approaches may contribute to conceptual confusion. Thus, these four studies (Ito \& Brotheridge, 2005; Kenny \& Bledsoe, 2005; McArdle et al., 2007, \& McIlveen et al., 2013) are not included in this review.

A full critical review of the psychometric properties of the career adaptability measures is beyond the scope of this paper. Instead, here are some guidelines that may assist researchers in identifying the best measure for their research. First, and most important, based on a clear theoretical framework, researchers need to select measures based on their intention to measure of readiness, resources, or responses. Second, they should decide if adaptability specific to the career is the main subject of inquiry, or if a more global measure of adaptability is required. Third, as some measures are more suited to students and others to adults, researchers must consider the population of their study. Fourth, if comparable research is the goal, then researchers would do well to choose the same instrument(s) that have been used in previous research. Finally, researchers should consider the practical constraints of data collection and select a measure of appropriate length.

One way to categorize thee measures presented above is to distinguish those that measure adaptability resources (e.g. the Career Adapt-Abilities Scale, the Career Futures Inventory) from those that measure adaptive responses (e.g. Hirschi, 2009). These categories are theoretically distinct and they provide a helpful structure in which to group existing research and therefore this review is structured according to adaptability resources and adaptive responses. Table 3 provides an overview of the correlates, predictors, and outcomes of adaptability resources and adaptive responses, with longitudinal studies marked with an asterisk. Many of the studies that use the term "predictor" or "outcome" are in actual fact 
cross-sectional studies. However, they are included under the categories of predictors and outcomes for two main reasons; either the authors themselves used the term "predictor" or "outcome", or one of the main goals of the paper was to establish if a variable "predicts" or contributes to career adaptability resources or responses, or if these relate to various outcomes based on theoretical propositions. Where relevant, studies that have investigated the mediating and moderating role of resources and responses will also be included. The qualitative literature that exists to date falls in the category of adaptability resources and will thus be included below in the relevant section. The literature review will also include the intervention studies aimed at increasing adaptability resources.

\section{Adaptability Resources}

Correlates. Starting first with personality, positive associations exist between career adaptability resources and conscientiousness, extraversion, agreeableness, and openness to experience; while associations with neuroticism are negative (Rossier, Zecca, Stauffer, Maggiori, \& Dauwalder, 2012; Rusu, Marirean, Hojbota, Gheramis, \& Gavriloaiei, 2015; Van Vianen, Klehe, Koen, \& Dries, 2012). Generally, career adaptability resources seems most clearly related to conscientiousness (Rossier et al., 2012; Teixeira, Bardagi, Lassance, Magalhães, \& Duarte, 2012). Rossier and colleagues (2012) also showed meaningful associations to the personality dimensions as defined in the alternative five factor model of personality.

Second, career adaptability resources are correlated to other factors closely related to

the self. They are negatively correlated to anxiety (Pouyaud, Vignoli, Dosnon, \& Lallemand, 2012), and positively correlated to self-esteem (Rusu et al., 2015; van Vianen et al., 2012), meaningfulness (Harry \& Coetzee, 2013), and individual global adaptability (Hamtiaux, Houssemand, \& Vrignaud, 2013).

Third, career adaptability resources are positively correlated to constructs related to goal pursuit and those that result in positive adjustment and coping. Here positive correlates 
include motivation (Pouyaud et al., 2012), promotion regulatory focus (Van Vianen et al., 2012), a better response to adversity (Tian \& Fan, 2014), hope and optimism (BuyukgozeKavas, 2014), and tenacious goal pursuit and flexible goal adjustment (Tolentino et al., 2013). The career adaptability resources are negatively correlated with a prevention regulatory focus (Van Vianen et al., 2012) and with the perceptions of internal or external barriers (Soresi, Nota, \& Ferrari, 2012).

Fourth, factors related to positive career development, job transitions, and career outcomes are also correlated to the career adaptability resources. Vocational identity status (Porfeli \& Savickas, 2012), employability (De Guzman \& Choi, 2013), promotability (Tolentino et al., 2013), career satisfaction (Chan \& Mai, 2015), boundaryless mindset and protean career attitudes (Chan et al., 2015), perceptions of professional competence and calling (Guo et al., 2014), perceptions of transferrable skills (Rocha, 2012; 2015) and career aspirations, the frequency of career exploration behaviours, and career decidedness (Urbanaviciute, Kairys, Pociute, \& Liniauskaite, 2014) are all positive correlates of career adaptability resources.

Predictors. Some researchers have tried to establish if certain individual characteristics or contextual factors can be considered predictors of career adaptability resources. First, the cross-sectional research shows that higher levels of emotional intelligence (Coetzee \& Harry, 2014a), a sense of control (Duffy, 2010) a future work self (Guan et al., 2014), proactivity, core-self-evaluations (Hirschi et al., 2015), hope and optimism (Wilkins et al., 2014), and a high sense of hardy control and a low tolerance for unpredictability (Coetzee \& Harry, 2014b) appear to predict career adaptability resources. Proactive personality is relevant too, but its positive effect on career adaptability appears to be through career decision-making self-efficacy (Hou, $\mathrm{Wu}, \& \mathrm{Liu}, 2014)$ or entrepreneurial alertness to opportunities (Uy, 2014). Some other individual characteristics such as, a high need for 
following social norms and high need for acceptance, might impede career adaptability resources (Stoltz, Wolff, Monroe, Farris, \& Mzahreh, 2013).

Certain contextual factors may also be positive predictors of career adaptability resources. These include career specific parental behaviours (Guan et al., 2015b) and positive relationships with parents (Soresi, Nota, Ferrai, \& Ginevra, 2014), social support (Duffy, 2010; Tian \& Fan, 2014), and unemployment (Duarte et al., 2012; Johnston et al., 2015; Maggiori, Johnston, Krings, Masoudi, \& Rossier, 2013). Experiences in education and training also shape career adaptability resources in that an individualized clinical learning environment and experience as a student leader associate contribute to the development of career adaptability resources (Tian \& Fan, 2014).

Several longitudinal studies exist that confirm some individual characteristics as predictors of career adaptability resources. A learning goal orientation, proactive personality, career optimism (Tolentino et al., 2014a), a higher self-esteem (Cai et al., 2015), career calling (Praskova, Hood, \& Creed, 2014), and making a vocational commitment and identification with this commitment (Negru-Subtirica et al., 2015) are all positive predictors of career adaptability resources. Self-doubt is a negative predictor (Negru-Subtirica, Pop, \& Crocetti, 2015). Over a 6 month period, Zacher (2014b) identified variables that predicted changes in career adaptability resources and found that age and future temporal focus predicted positive changes in overall adaptability, whereas education, extraversion, openness to experience, and core self-evaluations only predicted positive changes in some career adaptability dimensions, and neuroticism predicted negative changes in some dimensions. Furthermore, career planning and decision making precede career confidence when the developmental trend of these variables is examined together (Stringer, Kerpelman, \& Skorikov, 2011).

Outcomes. Researchers have proposed several outcomes of career adaptability resources in the categories of well-being; individual and organizational career outcomes; and 
employment outcomes. First, the dimensions of career adaptability are related to well-being in a transversal manner; control is positively associated to life satisfaction and positive affect, and negatively to negative affect, while confidence is positively associated to life satisfaction and positive affect (Konstam, Celen-Demirtas, Tomek, \& Sweeney, 2015). Overall adaptability is related to life satisfaction (Maggiori et al., 2013), and this relation is partially mediated by hope (Santilli, Nota, Ginevra, \& Soresi, 2014). Career adaptability resources are important for quality of life (Soresi et al., 2012) and reduced work stress (Maggiori et al., 2013).

A limited number of longitudinal studies have explored the relation between career adaptability resources and general and professional well-being. Johnston and colleagues (2015) found that career adaptability was positively associated to life satisfaction and selfrated health over 1 year. In a sample of older workers, Zacher and Griffin (2015) found that career adaptability resources were positively related to job satisfaction over four years and that this relation was stronger for relatively younger workers. Over three years, career adaptability (year 1) predicted higher positive affect and reduced negative affect (year 2), and by reducing negative affect, increased job satisfaction and reduced work stress (year 3) (Fiori, Bollmann, \& Rossier, 2015).

Career adaptability resources are associated to numerous beneficial individual and organizational outcomes in cross-sectional studies. First, adaptability resources corresponds positively to satisfaction outcomes such as career satisfaction (Chan \& Mai, 2015); salary and career satisfaction (with the effect persisting beyond the effects of demographics and organizational career management; Guan, Zhou, Ye, Jiang, \& Zhou, 2015); satisfaction with organizational retention factors such as career opportunities, work-life balance, training and development opportunities and characteristics of the job offered by the company (Coetzee \& Stoltz, 2015); academic satisfaction (Duffy, Douglass, \& Autin, 2015). Second, self-rated performance (Zacher, 2014a) and job performance ratings of fictitious employees improve 
with higher career adaptability resources (but the effect was smaller than that of conscientiousness and mental ability; Ohme \& Zacher, 2015). Career adaptability resources lead to increased exploration, vocational commitment, and identification with the vocational commitment over time (Negru-Subtirica et al., 2015), career decidedness (Gunkel, Schlaegel, Langella, \& Peluchette, 2010), and entrepreunerial intentions (Tolentino, Sedoglavich, Lu, Garcia, \& Restubog, 2014b). Adaptability resources also predict adapting responses (career planning, career decision-making difficulties, career exploration, and occupational selfefficacy) six months later (Hirschi et al., 2015). Furthermore, students with different profiles of adaptability resources showed different levels of adapting responses (Hirschi \& Valero, 2015).

On a more specific level, concerning performance and satisfaction outcomes, certain career adaptability dimensions emerge as relevant in relation to different outcomes; concern and confidence show specific cross-sectional relations to career satisfaction and self-rated performance, even when controlling for the Big Five personality traits and core selfevaluations (Zacher, 2014a). The cross-sectional relation between control and academic satisfaction is mediated by work volition; whereas career decision self-efficacy mediates the relations between concern, control, confidence, and academic satisfaction (Duffy et al., 2015). In a diary study, Zacher (2015) showed that daily career adaptability positively predicted daily task and career performance as well as daily job and career satisfaction. Further specific effects for the dimensions were also uncovered.

Third, career adaptability is related to factors associated with intentions to leave or stay with an organization in a cross-sectional manner. All four career adaptability dimensions are negatively related to intentions to leave the career and organization, but regression analyses show specific effects for control and confidence (Omar \& Noordin, 2013). Career satisfaction mediates the negative relation between career adaptability and turnover intentions (Chan \& Mai, 2015; Guan et al., 2015a). Career adaptability seems to correspond to increased 
perceptions of fit with the job and organization (Ferreira \& Coetzee, 2013; Ferreira, Coetzee, \& Masenge, 2013). These results suggest career adaptability contributes to increased organizational commitment and a desire to remain with the organization, possibly due to the positive relation between career adaptability and satisfaction outcomes as previously illustrated. However, other results show a contrary pattern.

Zacher, Ambiel, and Noronha (2015) showed, in a cross-sectional study, how career adaptability resources are negatively related to overall career entrenchment (perceived inability and / or unwillingness to pursue other options) suggesting that higher career adaptability (and in particular curiosity) could make individuals more likely to leave and consider other options. Individuals with high career adaptability may also feel less insecure because they perceive high levels of marketability at the same time point (Spurk, Kauffeld, Meinecke, \& Ebner, 2015). Contradictory findings may be explained by the use of different measures, but attention also needs to be given to possible mediators. For example, when measured at the same time point, career adaptability relates to perceived over qualification through two pathways; negatively through delegation, and positively through challenge (Yang, Guan, Lai, She, \& Lockwood, 2015) suggesting that a nuanced approach needs to be taken. Theoretically, because career adaptability is triggered by transitions implicated in expected and unexpected vocational tasks, career adaptability should be a relevant resource for job seekers and should contribute to positive outcomes not only in terms of finding a job, but also employment of good quality. Cross-sectional results show that unemployed individuals display higher levels of career adaptability (Duarte et al., 2012; Johnston et al., 2015; Maggiori et al., 2013) suggesting that it may be an important resource for unemployed individuals. Finally, for university students preparing to enter the labour market, career adaptability at time 1 (especially concern and control) positively predicted job search selfefficacy at time 2, which in turn related positively to employment status at time 3 (Guan et al., 2013). Future work self appears (time 1) to be an important predictor of this pathway in that it 
predicts job search self-efficacy and career-adaptability (time 2) which in turn positively predict employment status (time 3) (Guan et al., 2014).

Adaptability resources as a mediator or moderator. Due to the self-regulatory nature of adaptability resources, researchers have asked if resources may be mediating variables. A first group of studies have considered if adaptability resources mediate the relation between personality dimensions and outcomes. Adaptability resources mediate the relations between extraversion, activity, neuroticism, conscientiousness, and the outcome work engagement (Rossier et al., 2012). In particular, concern and curiosity mediate the relation between personality (openness to experience, agreeableness, conscientiousness, and the behavioural activation system) and career exploration (Li et al., 2015). The relations between the dimensions of orientations to happiness and work stress are partially mediated by control (Johnston et al., 2013a).

A second group of studies have examined the mediating effect of career adaptability resources on other individual characteristics, particularly those relevant to the career domain. Calling is a predictor of career decision self-efficacy, and concern and confidence are mediators of this effect (Douglas \& Duffy, 2014). Curiosity and confidence mediate the relation between hope and satisfaction in students (Wilkins et al., 2014). The relation between future work self and proactive skill development is fully mediated by confidence; while curiosity mediated the effect of future work self on proactive career networking (Taber \& Blankemeyer, 2015)

Finally, one studied examined the intervening effect of career adaptability resources on perceived contextual factors and found that the relations between the work environment (job strain and job insecurity) and general and professional well-being were partially mediated by career adaptability resources (Maggiori et al., 2013).

In contrast to numerous mediation studies, only two studies testing adaptability resources as a moderator were identified. The first cross-sectional study found that the 
relation between organizational career management and career satisfaction is stronger for those with higher levels of career adaptability resources (Guan et al., 2015a). The third, a longitudinal study, showed that the relation between future work self and job search selfefficacy was stronger for individuals higher in career adaptability resources (Guan et al., 2014).

Qualitative research on adaptability resources. Ebberwein and colleagues (2004) found that career adaptability corresponded to a more positive career transition experience and better coping for mid-career changers. Furthermore, mid-career changers use formal and informal learning to further develop their career adaptability (Brown, Bimrose, Barnes, \& Hughes, 2012). In their study on older women, McMahon, Watson, and Bimrose (2012) found that adaptability emerged in the description of the self in relation to external circumstances, and internal subjective experiences, and that the relevance of career adaptability was not limited to transitions only. Another study showed how older women report career adaptability and its sub-dimensions as being important resources for their interaction with the world of work (Whiston, Feldwisch, Evans, Blackman, \& Gilman, 2015). Bimrose and Hearne (2012) reviewed 4 different qualitative studies conducted from 20032012 in England, Norway, and Ireland and suggested that fresh attention needs to be given to how to best support the development of career adaptability, a crucial resource for career development. Finally, for emerging adults, previous motivation and parental support appeared as important precursors to the development of career adaptability resources (Shulman, Vasalampi, Barr, Livne, Nurmi, \& Pratt, 2014).

\section{Adaptive Responses}

Correlates. Intrinsic religiousness and spiritual awareness are positive correlates of career decision self-efficacy (Duffy \& Blustein, 2005).

Predictors. Individual factors such as career concerns, learning orientation and performance-prove orientation (Yousefi, Abedi, Baghban, Eatemadi, \& Abedi, 2011) and 
hope (Hirschi, 2014) were identified as predictors of adaptability responses in a crosssectional manner. Over 10 months, perceived social support, positive emotional disposition, a non-immigrant background, and continuing vocational education were predictors of career adaptability responses; career choice readiness, planning, and exploration (Hirschi, 2009). Contextual factors in the form of education and labour market experiences are relevant too. The quality of an internship also appears to contribute to the development of career exploration, decision-making, commitment, and decision-making self-efficacy over time (Gamboa, Paixão, \& de Jesus, 2014). Being made redundant increased adaptive responses at a later time point, whereas job insecurity inhibited career planning (Klehe, Zikic, van Vianen, \& De Pater, 2011).

Outcomes. In longitudinal studies, adaptability responses contribute to a sense of power and life-satisfaction (Hirschi, 2009) and to the stability and realism of career aspirations (Hirschi, 2010). Career planning positively predicts organizational loyalty whereas career exploration negatively predicted career loyalty and positively predicted turnover intentions, job-search behaviors, and actual turnover (Klehe et al., 2011). Career adaptability responses in the form of career exploration, planning, and decision-making, positively predict re-employment quality with this effect partly explained by job search strategies (Koen, Klehe, Van Vianen, Zikic, \& Nauta, 2010; Zikic \& Klehe, 2006). Career adaptability responses are also predictive of who seeks out career counselling - adolescents with lower levels of career decidedness are more likely to seek out counselling (Balin \& Hirschi, 2010).

Adaptability responses as a mediator or moderator. First concerning mediation, career adaptability responses mediated the relation between social support and job satisfaction (Han \& Rojewski, 2015) and between social support and career concerns (Yousefi et al., 2011). Second, concerning moderation, one study found that the positive relation between goal engagement and disengagement was stronger when adaptability responses (career planning, exploration, and career self-efficacy) were higher (Praskova, et al., 2013). Another 
cross-sectional study found that career adaptability (measured as work stress adaptability and uncertainty adaptability) did not moderate the relation between job demands and burnout (Cotter \& Fouad, 2012).

\section{Interventions Aimed at Increasing Adaptability Resources}

A select number of studies exist that have focused on interventions to develop and promote career adaptability resources. One of the goals of career counselling is to increase individual resources, such as career adaptability (Hirschi, 2012). To this end, studies have found that narrative counselling (Del Corso \& Rehfuss, 2011; Del Corso \& Briddick, 2015; Maree \& Gerruty, 2014), the constructivist résumé technique (Scholl \& Cascone, 2010), and a brief career counselling intervention (Stauffer, Maggiori, Froidevaux, \& Rossier, 2014) all contributed to the enhancement of career adaptability resources. However, all these studies relied on self-reports of participants and did not include pre- and post-measurements of career adaptability. With this goal in mind, three studies were identified that measured changes in adaptability. A six-week intervention proved to be more successful in developing career adaptability resources than a single career information session, particular for individuals with insecure, pessimistic or superficial coping styles (Janeiro, Mota, \& Ribas, 2014). Koen, Klehe and Van Vianen's (2012) longitudinal field quasi-experiment showed an increase in concern, control, and curiosity for participants of a training program aimed at developing career adaptability resources. Furthermore, participants of the program reported higher employment quality. Finally, an academic career course aimed at fostering career exploration resulted in significant increases in self and environment exploration, and marginal improvements in career adaptability (Cheung \& Jin, 2015).

\section{Current State of the Career Adaptability Research and Directions for Future}

\section{Research}

The research finidings thus far shows that adaptability resources are indeed psychosocial resources that contribute to positive transitions and personal functioning in 
teenagers, young adults, adults, and older workers. Adaptability responses are also related to important individual and career outcomes. The dimensionality of career adaptability resources and responses - whether represented as the four dimensions of concern, control, curiosity, and confidence, or as, for example, career planning as different to career exploration - is pertinent. The literature on career adaptability is dominated by quantitative studies. However, there are a number of promising qualitative studies that provide important richness and depth to the concept and highlight the relevance of career adaptability resources in the personal life story.

Based on the career adaptability research findings to date, I suggest two major goals for future career adaptability research; first, theory building, and second, advancements in the measurement of career adaptability, with each discussed in turn next.

\section{Goal 1: Theory Building}

The research to date on career adaptability represents a promising start for this field. Still, this field would benefit from a clear theory from which to generate testable propositions that can form the springboard for further research. To this end, three theory building options are presented here. First, CCT is undoubtedly a relevant starting point for further theoretical refinement. Here, researchers may wish to consider further refinement of the adaptation sequence, a point I discuss further below. Alternatively, they may wish to focus on generating testable theoretical propositions based on CCT or examining the existing the theoretical propositions made in CCT (Savickas, 2002, 2005) and seeing how they could be tested in career adaptability research. For example, a theory proposition in CCT states that "a minicycle of growth, exploration, establishment, management, and disengagement occurs during transitions... as well as each time an individual's career is destabilized" (p. 46), presenting an opportunity for researchers to test how career adaptability is relevant during this minicycle.

Second, researchers could also look to other well-known theories of career choice and development from which to build thereotical propositions. For example, although trait-factor 
or person-environment fit theories are quite static and not primarily focused on change and adaptation, the Theory of Work Adjustment Dawis (2005) does address adaptation behaviours individuals engage in to ensure a better fit. Or, Social Cognitive Career Theory (SCCT; Lent, 2005 ) is more dynamic in nature and aims to explain how interests develop, how career choices are made, and how individuals perform. SCCT acknowledges that "people are able to change, develop, and regulate their own behaviour over time and in different situations" (Lent, 2005, p. 103) suggesting a need for adaptability. Finally, postmodern or contemporary career concepts such as the protean career orientation (for a review see Sullivan \& Baruch, 2009) positions adaptability as an important meta-competency, presenting yet another avenue for theoretical development. Thus some of the other main career choice and development theories imply, with varying degrees of specificity, that adaptability is required (to a greater or less extent) without addressing adaptability as their focal construct. This gives the possibility that career adaptability researchers could ground their hypotheses in various different career theories.

Third, as already done in some studies, researchers can identify other relevant theories on which to build their research questions. In particular, this represents a promising manner for the relevance of career adaptability to be extended into other domains, such as Organizational Psychology. For example, existing research shows that career adaptability is important for a number of organizationally relevant outcomes such as loyalty and turnover intentions (Guan et al., 2015a), yet a clear theoretical explanation to account for these findings and on which to base future research is not yet available. Or, career adaptability could be an approach to understanding stress and coping at work (Leong \& Ott-Holland, 2014), and here researchers may wish to develop a theoretical perspective that combines career and organizational theories, such as the Job Demands-Resources model (e.g. Cotter \& Fouad, 2012). The refined theoretical basis for career adaptability research should attempt to provide answers to the following key questions (amongst others) that have emerged from the 
existing research on career adaptability. These are presented next along with suggestions for future research

How are resources and responses related? The empirical research that has aimed to distinguish resources from responses, does find that resources are distinct from more stable and trait-like adaptivity predispositions and actual adapting responses and that adaptability resources are mediators between readiness and responses (Hirschi et al., 2015; Hirschi \& Valero, 2015; Tolentino et al., 2013; Tolentino et al., 2014a). Studies that propose adaptability resources as mediators aim to test the capacity of these resources to act as a process variable involved in the translation of individual characteristics into behaviours and outcomes or as involved in the response to the context. Positioning adaptability resources as a mediator appears to fit well with the conceptualization of the adaptability resources as a selfregulation capacity (Savickas \& Porfeli, 2012) and the above-mentioned studies confirm this notion empirically. Career adaptability is a psychosocial resource involved in self-regulation, whether it be regulation of individual characteristics, or regulation in response to the environment. Although less research on career adaptability responses as a mediator has been conducted under the label of career adaptability research, in the Career Construction Theory (Savickas, 2005), responses would be the mediator between resources and results, and thus further testing of this casual mechanism is also encouraged. Using adaptability resources or responses as a moderator appears less common. However, as Rossier (2015a; 2015b) noted, both moderation and mediation processes are implicated in self-regulation, suggesting that studies using career adaptability resources as a moderator may add to our understanding of the regulation process.

Adaptability resources appear distinct from responses, yet Hirschi and colleagues (2015) found no clear relations between adaptability resources and the theoretically corresponding adapting response such as between curiosity and career exploration, suggesting rather that adaptability resources have a general and broad impact on adapting responses. 
Thus, an area of future research would be to investigate what the precise impact of adaptability resources on responses (and in turn results) actually is.

Another open question concerns the causal order of the adapting chain. Some research has confirmed the sequence of readiness to resources to responses (e.g. Tolentino et al., 2014a), whereas other research has shown that career planning and decision making (responses) proceeded career confidence (resource; Stringer et al., 2011). It is probable that there is a feedback loop from responses to resources such that successful responding results in individuals as appraising their resources as sufficient. Future research could explore this possibility.

\section{Does career adaptability show different patterns of activation or depletion in}

response to professional situations? Career adaptability resources and responses appear to be activated in relation to some professional aspects, but other professional situations seem to correspond to lower levels of resources and responses. For unemployed individuals and for those who have experienced professional transitions career adaptability resources levels are elevated (Duarte et al., 2012; Johnston et al., 2015; McMahon et al., 2012). Similarly, being made redundant increases career adaptive responses or behaviours (Klehe et al., 2011). While, on the contrary, facing job insecurity and job strain contributes to decreased career adaptability resources and responses (Klehe et al., 2011; Maggiori et al., 2013). An explanation is thus needed that can account for these patterns of results.

Mischel and Shoda (1995) proposed that the psychological features of different situations are key and that it is these features that trigger an activation or inhibition of an individual response. Similarly, as suggested by appraisal theory, individuals first appraise features of situations as positive, neutral or stressful (Lazarus \& Folkman, 1984; Lazarus, 1999). Subsequently, stressful situations can be further appraised as loss, challenge, and/or threat. Thus, the meaning attached to situations is important for how individuals adapt and regulate in response to situations (Mischel, 2009; Shoda, LeeTiernan, \& Mischel, 2002). 
In considering the question of why, for example, unemployment appears to activate resources and job insecurity decrease resources and responses, it may be necessary to reflect on the psychological features and meaning of these situations. In the case of job insecurity, individuals fear losing their jobs and they anticipate the loss of the benefits associated with work, but the situation is still uncertain (DeWitte, 2005; Greenhalgh \& Rosenblatt, 2010). This situation could thus be appraised as threatening. Once unemployed, individuals have no doubt experienced a sense of loss, but their situation is certain. Unemployed individuals know that they need to start making decisions and looking for new employment. In this sense, individuals may, paradoxically, feel more in control than when in situations of uncertain employment. In this sense, being unemployed may be appraised as more challenging rather than threatening.

Thus, the activation of career adaptability resources and responses may depend on an individual feeling a certain sense of personal control and responsibility, and importantly possibility, to change the situation. Alternatively, career adaptability may become depleted or inhibited in situations that are appraised as threatening. Further research could explore this theoretical proposition and test the hypothesis that it is situations that are perceived as threatening that contribute to the reduction of career adaptability, and situations that are perceived as challenging that activate career adaptability. The categorization of situations as threatening or not may also depend on if these situations or events are predictable and expected and as such represent normative events, or if they are unexpected and nonnormative. This research would need to account for an individual's adaptive readiness, as according to CCT (Savickas, 2005) this would proceed resources and responses.

It may also be necessary to consider individual characteristics or environmental factors that could contribute to the development and maintenance of resources and responses, or alternatively the inhibition of these same characteristics. As summarized above, various individual characteristics and demographic factors play a role in the development or 
enhancement of adaptability resources and responses (e.g. Duffy \& Blustein, 2005; Hirschi, 2009; Tolentino et al., 2014a; Zacher, 2014b). Certain environmental features, such as parental and family support, are important too (e.g. Guan et al., 2015b; Tian \& Fan, 2014). Thus the activation or inhibition of resources and responses may depend on the presence of these other characteristics. In particular, individual characteristics may specify under what conditions, or for whom, career adaptability may show different levels, by, for example, offering some protection against threatening professional situations.

Longitudinal research, with multiple measurement points, on this theme would be particularly valuable in contributing to understanding the developmental trend of career adaptability, as well as identifying if career adaptability consists of trait and state components. Other approaches to measurement, such as daily measures of career adaptability resources that are able to assess the within-person variance, as well as the intra-individual variance of these resources provide further insights into the stable and fluid aspects of career adaptability (Zacher, 2015). Research with different time frames would also help to determine if all the career adaptability dimensions change together, such that the level of an individual's career adaptability resources or responses increases or decreases in a unified manner, or if the dimensions are differentially affected suggesting that the shape of an individual's career adaptability profile changes (see also Hirschi \& Valero, 2015; Stringer et al., 2011).

Do the positive effects of adaptability resources and responses change over time?

The research reported here supports career adaptability resources and responses as positive correlates and predictors of a number of beneficial individual well-being, work, and career outcomes. Further longitudinal research is needed to explore the positive effects of these resources and responses over longer time frames and in specific situations. As career adaptability responses are more behavioural in their nature, it is plausible that these are not consistently displayed, but rather only as needed. And, if career adaptability resources and 
responses change over time, as suggested above, then it is possible that the positive contribution of these may be boosted or diminished over time.

For example, repeated exposure to stressors results in an accumulation of threat and the increased possibility of reactions to events that are more severe than if the individual had not been under continued stress (Stawski, Sliwinski, Almeida, \& Smyth, 2008). In line with appraisal theory (Lazarus \& Folkman, 1984) when individuals appraise situations as threatening, they are more likely to appraise their resources as insufficient, which in turn should lead to sub-optimal responding. Furthermore, conservation of resources theory (Hobfoll, 1989), suggests that resource loss is associated with threatening situations. In turn, compromised well-being results in individuals appraising resources as inadequate (Vander Elst, Van den Broeck, De Cuyper, \& De Witte, 2014). Thus, with sustained exposure to difficult professional or vocational situations, the threat to career adaptability resources may increase, which in turn limits the potential of resources to protect well-being and to contribute to proactive regulation responses and positive outcomes. Furthermore, a select number of studies (Johnston et al., 2015; Zacher \& Griffin, 2015) have shown how the longitudinal associations between resources and well-being outcomes vary according to some other factors such age or the professional situation. Thus, researchers may wish to consider pertinent moderator variables in tests of the association between career adaptability resources and responses and well-being.

\section{Goal 2: The Measurement and Modelling of Career Adaptability}

From the overview of measures given above, it should be clear that researchers are not all referring to the same concept even when the label "career adaptability" is used. Even amongst all the scales measuring career adaptability based on Savickas' conceptualization, there is a lack of clarity. Firstly, the dimensions of career adaptability (concern, control, confidence and curiosity) are intended as adaptability resources that are distinct from adaptive readiness and adaptive responses (Savickas, 2013). However, the item content does not 
consistently reflect this distinction (see appendix 1 for sample items from each measure). For example, a curiosity item from the CWAQ, "like exploring, fantasizing, imagining, thinking in an unconventional way, finding novel solutions" could be taken as a measure of adaptive readiness, in that its item content could be seen as quite similar to an item from a personality scale designed to measure openness "I have a very active imagination" or "I enjoy concentrating on a fantasy or daydream, exploring all its possibilities, letting it grow and develop" (Costa \& McCrae, 1992). Or, a curiosity item from the Career Adapt-Abilities Scale, "looking for opportunities to grow as a person" is more behaviourally oriented and thus reflects an adapting response. Secondly, differences are present across scales even when the same dimension is measured. For example, confidence in the Career Adapt-Abilities Scale is measured with the following items; "performing tasks efficiently", "taking care to do things well", "learning new skills", "working up to my ability", "overcoming obstacles" and "solving problems". These items capture an element of self-efficacy and a desire to develop and work well. Confidence in the Career Maturity Inventory - Form C is measured with the following items "I have so many interests that it is hard to choose just one occupation", "Everyone seems to tell me something different; as a result I don't know what kind of work to choose", "I keep changing my occupational choice", "I often daydream about what I want to be, but I really have not chosen an occupation yet", "there are so many things to consider in choosing an occupation, it is hard to make a decision", and "I can't understand how some people can be so certain about what they want to do". The content of these items reflects difficulty in career choice and career decision-making, and thus is different to the confidence subscale in the Career Adapt-Abilities Scale.

Thus, future research needs to address these measurement challenges by developing new measures that adequately capture the distinction between adaptability resources and adaptability responses. And, researchers need to clearly state if they interested in resources or responses, and then choose measures that accurately reflect this. Beyond this, country-specific 
norms could be developed to support the implementation of the Career Adapt-Abilities Scale by allowing for interpretation of test results within a particular context. Savickas and Porfeli (2012) hinted at this possibility when they mentioned, "countries vary in the degree to which they prompt the formation of adaptability because they provide different opportunities and imperatives to develop and express psychosocial resources and transactional competencies" (p. 663). Additionally, in support of the psychosocial nature of career adaptability resources, in different contexts, the scale items could be adjusted, or additional items included, to ensure that measurement reflects cultural uniqueness (Savickas \& Porfeli, 2012). Studies that were part of the international validation of the Career Adapt-Abilities Scale also showed that adjustments to account for language and cultural uniqueness could be made. For example, the authors of the studies in Iceland (Vilhjalmsdottir, Kjartansdóttir, Smáradóttir, \& Einarsdóttir 2012), the Netherlands (Van Vianen et al., 2012), Portugal (Duarte et al., 2012), and China (Hou, Leung, Li, Li, \& Xu, 2012) all mentioned that modifications (such as response scales, wording, and number of items) would enhance the use of the Career Adapt-Abilities Scale in each particular country. Researchers in Iceland adopted a culture-sensitive approach, and found that two additional dimensions, co-operation (previously suggested as a dimension by Savickas (2009)) and contribution, could be meaningfully added to the four existing career adaptability dimensions (Einarsdóttir, Vilhjálmsdóttir, Smáradóttir, \& Kjartansdóttir, 2015).

In addition, methodological advancements pertaining to the statistical modelling of career adaptability may be beneficial to the field. For example, bifactor models (Brunner, Nagy, \& Wilhelm, 2012; Reise, 2012) that account for general or shared variance across dimensions, but also the unique variance of dimensions, might be useful in the case of career adaptability to identify the specific roles played by the dimensions. The dimensions overlap and are correlated, but are still conceptually different (Savickas, 2005; Savickas \& Porfeli, 2012) and, as has been shown by the research presented above, have unique effects. 
Researchers may also want to consider measuring career adaptability resources as a latent variable (Hirschi \& Valero, 2015) rather than only as a total score which is commonly done.

\section{Practical Implications}

The practical implications of career adaptability as it relates to career guidance and counselling practice, interventions, and organizational life will be discussed here. The assessment of career adaptability can be used as a screening tool by career guidance counsellors and practitioners. The presence of adaptability resources indicate important strengths that individuals can capitalize on as they develop their careers. The absence of a resource will either be evident in the results of a career adaptability assessment or will be suggested by the presence of a particular career problem. For example, Savickas (2005) outlined how indifference may indicate a lack of concern, or unrealism a lack of curiosity. Once a gap has been identified, then a targeted career intervention can be applied. Orientation exercises, for example, can be used to develop the resource of concern with its associated competence of planning (Savickas, 2005).

Considering that adaptability resources can and do change, and are important precursors to adaptability responses, it seems an area of valuable practice is the design, implementation, and evaluation of interventions aimed at increasing career adaptability. More research on interventions would enhance the credibility of the important work done in this field, and also support other calls made in the literature for advancements in establishing the efficacy and clinical significance of career interventions in general (Brown, 2015).

For Industrial and Organizational Psychologists, Human Resource Practitioners and mangers in organizations, career adaptability is relevant for post-career choice work adjustment (Leong \& Ott-Holland, 2014). Considering that career adaptability resources and responses are important for a number of individual and organizational outcomes, practitioners and managers in organizations may find benefits in nurturing adaptability resources and responses, and in recognizing that certain work experiences foster career adaptability 
resources and responses (O’Connell, McNeely, \& Hall, 2008; van Vianen, De Pater, \& Preenen, 2009). Additionally, because of the coping and self-regulatory behaviours associated with adaptability (e.g. Savickas, 2005), adaptability is also relevant to stress and coping processes of employees at work (Leong \& Ott-Holland, 2014), suggesting that an additional benefit of nurturing adaptability may be increased well-being of workers, a sought after outcome in organizational life.

\section{Conclusion}

It is clear that Goodman's (1994) call for further research on career adaptability has been answered. Both adaptability resources and adaptive responses have been studied under the banner of career adaptability research, but researchers need to specify which they are interested in and choose appropriate measures. Resources and responses are not only pertinent for the fields of vocational and career psychology, but also shows promise for the domain of organizational psychology. There are nonetheless important avenues for future research that would further contribute to the theoretical advancement and practical utility of career adaptability. 


\section{References}

*Akın, A., Kaya, Ç., Arslan, S., Demir, T., Sarıçam, H., \& Uysal, R. (2014). Turkish version of the Career Adapt-Abilities Scale (CAAS): The validity and reliability study. In Chaos, Complexity and Leadership 2012 (pp. 499-505). The Netherlands: Springer.

*Balin, E., \& Hirschi, A. (2010). Who seeks career counselling? A prospective study of personality and career variables among Swiss adolescents. International Journal for Educational and Vocational Guidance, 10(3), 161-176. doi:10.1007/s10775-0109183-y

*Bimrose, J., \& Hearne, L. (2012). Resilience and career adaptability: Qualitiative studies of adult career counseling. Journal of Vocational Behavior, 81, 338-344. doi: 10.1016/j.jvb.2012.08.002

Brown, S. D. (2015). Career intervention efficacy: Making a difference in people's lives. In P.J Hartung, M. L Savickas, \& W. Bruce (Eds.). APA Handbook of career intervention. Volume 1: Foundations (pp. 61-77). Washington, DC: APA.

*Brown, A., Bimrose, J., Barnes, S.-A., \& Hughes, D. (2012). The role of career adaptabilities for mid-career changers. Journal of Vocational Behavior, 80, 754-761. doi:10.1016/j.jvb.2012.01.003

Brunner, M., Nagy, G., \& Wilhelm, O. (2012). A tutorial on hierarchically structured constructs. Journal of Personality, 80, 796-846. doi:10.1111/j.14676494.2011.00749.x

*Buyukgoze-Kavas, A. (2014). Validation of the Career Adapt-Abilities Scale-Turkish form and its relation to hope and optimism. Australian Journal of Career Development, 23, 125-132. doi: $10.1177 / 1038416214531931$

*Cai, Z., Guan, Y., Li, H., Shi,W., Guo, K., Liu, Y., Li, Q., Han, X., Jiang, P., Fang, Z. \& Hua, H. (2015). Self-esteem and Proactive Personality as Predictors of Future Work 
Self and Career Adaptability: An Examination of Mediating and Moderating

Processes. Journal of Vocational Behavior, 86, 86-94. doi: 10.1016/j.jvb.2014.10.004

*Chan, K. Y., Uy, M. A., Moon-ho, R. H., Sam, Y. L., Chernyshenko, O. S., \& Yu, K. Y. T. (2015). Comparing two career adaptability measures for career construction theory: Relations with boundaryless mindset and protean career attitudes. Journal of Vocational Behavior, 87, 22-31. doi:10.1016/j.jvb.2014.11.006

*Chan, S. H. J., \& Mai, X. (2015). The relation of career adaptability to satisfaction and turnover intentions. Journal of Vocational Behavior, 89, 130-139. doi:10.1016/j.jvb.2015.05.005

*Cheung, R., \& Jin, Q. (2015). Impact of a career exploration course on career decision making, adaptability, and relational support in Hong Kong. Journal of Career Assessment. Advance online version. doi:10.1177/1069072715599390

*Coetzee, M., \& Harry, N. (2014a). Emotional intelligence as a predictor of employees' career adaptability. Journal of Vocational Behavior, 84, 90-97.

doi:10.1016/j.jvb.2013.09.001

*Coetzee, M., \& Harry, N. (2014b). Gender and hardiness as predictors of career adaptability: an exploratory study among Black call centre agents. South African Journal of Psychology, 45, 81-92. doi:10.1177/0081246314546346

*Coetzee, M., \& Stoltz, E. (2015). Employees' satisfaction with retention factors: Exploring the role of career adaptability. Journal of Vocational Behavior, 89, 83-91. doi:10.1016/j.jvb.2015.04.012

Costa, P.T., \& McCrae, R.R. (1992). Revised NEO Personality Inventory (NEO-PR-I), the Five Factor Inventory (NEO-FFI): Professional Manual. Odessa, FL: Psychological Assessment Resources 
*Cotter, E. W., \& Fouad, N. A. (2012). Examining burnout and engagement in Layoff Survivors: The role of personal strengths. Journal of Career Development, 40, 424444. doi:10.1177/0894845312466957

*Creed, P. A., Fallon, T., \& Hood, M. (2009). The relationship between career adaptability, person and situation variables, and career concerns in young adults. Journal of Vocational Behavior, 74, 219-229. doi:10.1016/j.jvb.2008.12.004

Dawis, R. V. (2005). The Minnesota Theory of Work Adjustment. In Brown, S. D., \& Lent, R. W. (Eds.). (2005). Career development and counseling: Putting theory and research to work (pp. 3-23). Hoboken, NJ: Wiley.

*Del Corso, J., \& Briddick, H. S. (2015). Using audience to foster self-narrative construction and career adaptability. In P. J. Hartung, M. L. Savickas, \& W. B. Walsh (Eds.), APA handbook of career intervention: Applications (Vol. 2) (pp. 255-268).Washington, DC: American Psychological Association.

*Del Corso, J., \& Rehfuss, M. C., (2011). The role of narrative in career construction theory. Journal of Vocational Behavior, 79, 334-339. doi:10.1016/j.jvb.2011.04.003

*de Guzman, A. B., \& Choi, K. O. (2013). The relations of employability skills to career adaptability among technical school students. Journal of Vocational Behavior, 82, 199-207.doi:10.1016/j.jvb.2013.01.009

DeWitte, H. (2005). Job insecurity: Review of the international literature on definitions, prevalence, antecedents and consequences. SA Journal of Industrial Psychology, 31, 1-6. doi:10.4102/sajip.v31i4.200

*Di Maggio, I., Ginevra, M. C., Laura, N., Ferrari, L., \& Soresi, S. (2015). Career Adapt Abilities Scale-Italian Form: Psychometric proprieties with Italian preadolescents. Journal of Vocational Behavior. Advance online version.

doi:10.1016/j.jvb.2015.08.001 
*Douglass, R. P., \& Duffy, R. D. (2014). Calling and Career Adaptability among Undergraduate Students. Journal of Vocational Behavior, 86, 58-65. doi:10.1016/j.jvb.2014.11.003

*Duarte, M. E., Soares, M. C., Fraga, S., Rafael, M., Lima, M. R., Paredes, I., ... Djaló, A. (2012). Career Adapt-Abilities Scale-Portugal Form: Psychometric properties and relationships to employment status. Journal of Vocational Behavior, 80, 725-729. doi:10.1016/j.jvb.2012.01.019

*Duffy, R. D., (2010). Sense of control and career adaptability among undergraduate students. Journal of Career Assessment, 18, 420-430. doi:10.1177/1069072710374587

*Duffy, R. D., \& Blustein, D. L. (2005). The relationship between spirituality, religiousness, and career adaptability. Journal of Vocational Behavior, 67, 429-440. doi:10.1016/j.jvb.2004.09.003

*Duffy, R. D., Douglass, R. P., \& Autin, K. L. (2015). Career adaptability and academic satisfaction: Examining work volition and self-efficacy as mediators. Journal of Vocational Behavior, 90, 46-54. doi:10.1016/j.jvb.2015.07.007

*Ebberwein, C. A., Krieshok, T. S., Ulven, J. C., \& Prosser, E. C. (2004). Voices in transition: Lessons on career adapt-ability. The Career Development Quarterly, 52, 292-308. doi:10.1002/j.2161-0045.2004.tb00947.

*Einarsdottir, S., Vilhjàlmsdottir, G., Smaradottir, S. B., \& Kjartansdottir, B. (2015). A culture-sensitive approach in the development of the Career Adapt-Abilities Scale in Iceland: Theoretical and operational considerations. Journal of Vocational Behavior, 89, 172-181. doi:10.1016/j.jvb.2015.06.006

*Ferreira, N., \& Coetzee, M. (2013). Psychological career meta-competencies in relation to job embeddedness among human resource employees. African Journal of Business Management, 7(15), 1369-1378. 
*Ferreira, N., Coetzee, M. \& Masenge, A. (2013). Psychological career resources, career adaptability and hardiness in relation to embeddedness and organizational commitment. Journal of Psychology in Africa, 23(1), 31-40.

*Fiori, M., Bollmann, G., \& Rossier, J. (2015). Exploring the path through which career adaptability increases job satisfaction and lowers job stress: The role of affect. Journal of Vocational Behavior. Advance online version. doi:10.1016/j.jvb.2015.08.010

*Gamboa, V., Paixão, M. P., \& de Jesus, S. N. (2014). Vocational profiles and internship quality among Portuguese VET students. International Journal for Educational and Vocational Guidance, 14, 1-24. doi:10.1007/s10775-014-9268-0

*Glavin, K. (2015). Measuring and assessing career maturity and adaptability. In P. J. Hartung, M. L. Savickas, W. W. Bruce (Eds.). APA handbook of career intervention, Volume 2: Applications. APA handbooks in psychology. (pp. 183-192). Washington, DC: American Psychological Association. http://dx.doi.org/10.1037/14439-014 Goodman, J. (1994). Career adaptability in adults: A construct whose time has come. The Career Development Quarterly, 43, 74-84. doi: 10.1002/j.2161-0045.1994.tb00848.x

Greenhalgh, L., \& Rosenblatt, Z. (2010). Evolution of research on job insecurity. International Studies of Management and Organization, 40, 6-19. doi:10.2753/IMO0020-8825400101

*Guan, Y., Deng, H., Sun, J., Wang, Y., Cai, Z., Ye, L., ... Li, Y. (2013). Career adaptability, job search self-efficacy and outcomes: A three-wave investigation among Chinese university graduates. Journal of Vocational Behavior, 83, 561-570. doi:10.1016/j.jvb.2013.09.003

*Guan, Y., Guo, Y., Bond, M. H., Cai, Z., Zhou, X., Xu, J., ... \& Ye, L. (2014). New job market entrants' future work self, career adaptability and job search outcomes: examining mediating and moderating models. Journal of Vocational Behavior, 85, 136-145. doi:10.1016/j.jvb.2014.05.003 
*Guan, Y., Zhou, W., Ye, L., Jiang, P., \& Zhou, Y. (2015a). Perceived organizational career management and career adaptability as predictors of success and turnover intention among Chinese employees. Journal of Vocational Behavior, 88, 230-237. doi:10.1016/j.jvb.2015.04.002

*Guan, Ya., Wang, F., Liu, H., Ji, Y., Jia, X., Fang, Z., Li, Y., Hua, H., \& Li, C. (2015b). Career-specific parental behaviors, career exploration and career adaptability: A threewae investigation among chinese undergraduates. Journal of Vocational Behavior, 86, 95-103. doi:10.1016/j.jvb.2014.10.007

*Guo, Y., Guan, Y., Yang, X., Xu, J., Zhou, X., She, Z., ... \& Fu, M. (2014). Career adaptability, calling and the professional competence of social work students in China: A career construction perspective. Journal of Vocational Behavior, 85, 394-402. doi: 10.1016/j.jvb.2014.09.001

*Gunkel. M., Schlaegel, C., Langella, I.M., Peluchette, J. V. (2010). Personality and career decisiveness: An international empirical comparison of business student's career planning. Personnel Review, 39, 503-524. doi:10.1108/00483481011045443

*Hamtiaux, A., Houssemand, C., \& Vrignaud, P. (2013). Individual and career adaptability: Comparing models and measures. Journal of Vocational Behavior, 83, 130-141. doi:10.1016/j.jvb.2013.03.006

*Han, H., \& Rojewski, J. W. (2015). Gender-specific models of work-bound Korean adolescents' social supports and career adaptability on subsequent job satisfaction. Journal of Career Development, 42, 149-164. doi:10.1177/0894845314545786

*Harry, N., \& Coetzee, M. (2013). Sense of coherence, career adaptability and burnout of early-career Black staff in the call centre environment. SA Journal of Industrial Psychology, 39, 1-10. doi:10.4102/sajip.v39i2.1138

*Hartung, P., Porfeli, E., \& Vondracek. F. W (2008). Career adaptability in childhood. Career Development Quarterly, 57, 63-74. doi:10.1002/j.2161-0045.2008.tb00166.x 
*Hirschi, A. (2009). Career adaptability development in adolescence: Multiple predictors and effect on sense of power and life satisfaction. Journal of Vocational Behavior, 74, 145-155. doi:10.1016/j.jvb.2009.01.002

*Hirschi, A. (2010). Swiss Adolescents' Career Aspirations: Influence of context, age, and career adaptability. Journal of Career Development, 36, 228-245. doi: $10.1177 / 0894845309345844$

*Hirschi, A. (2012). The career resources model: An integrative framework for career counsellors. British Journal of Guidance \& Counselling, 40, 369-383. doi:10.1080/03069885.2012.700506

*Hirschi, A. (2014). Hope as a resource for self-directed career management: Investigating mediating effects on proactive career behaviors and life and job satisfaction. Journal of Happiness Studies, 15, 1495-1515. doi:10.1007/s10902-013-9488-x

*Hirschi, A., Herrmann, A., \& Keller, A. C. (2015). Career adaptivity, adaptability, and adapting: A conceptual and empirical investigation. Journal of Vocational Behavior, 87, 1-10. doi:10.1016/j.jvb.2014.11.008

*Hirschi, A., \& Valero, D. (2015). Career adaptability profiles and their relationship to adaptivity and adapting. Journal of Vocational Behavior, 88, 220-229. doi:10.1016/j.jvb.2015.03.010

Hobfoll, S. E. (1989). Conservation of resources: A new attempt at conceptualizing stress. American psychologist, 44, 513-524. doi:10.1037/0003-066X.44.3.513

*Hou, Z. J., Leung, S. A., Li, X., Li, X., \& Xu, H. (2012). Career adapt-abilities scale-China form: Construction and initial validation. Journal of Vocational Behavior, 80, 686691.doi: 10.1016/j.jvb.2012.01.006

*Hou, C., Wu, L., \& Liu, Z. (2014). Effect of proactive personality and decision-making selfefficacy on career adaptability among Chinese graduates. Social Behaviour and Personality, 42, 903-912. doi:10.2224/sbp.2014.42.6.903 
Ito, J. K., \& Brotheridge, C. M. (2005). Does supporting employees' career adaptability lead to commitment, turnover, or both? Human Resource Management, 44, 5-19. doi:10.1002/hrm.20037

*Janeiro, I. N., Mota, L. P., Ribas, A. M. (2014). Effects of two types of career interventions on students with different career coping styles. Journal of Vocational Behavior, 85, 115-124. doi:10.1016/j.jvb.2014.05.006

*Johnston, C. S., Luciano, E. C., Maggiori, C., Ruch, W., \& Rossier, J. (2013a). Validation of the German version of the career adapt-abilities scale and its relation to orientations to happiness and work stress. Journal of Vocational Behavior, 83, 295-304. doi:10.1016/j.jvb.2013.06.002

*Johnston, C. S, Broonen, J. P., Stauffer, S., Hamtiaux, A., Pouyaud, J., Zecca, G., ... \& Rossier, J. (2013b). Validation of an adapted French form of the Career AdaptAbilities Scale in four Francophone countries. Journal of Vocational Behavior, 83, 110. doi: $10.1016 /$ j.jvb.2013.02.002

*Johnston, C. S., Maggiori, C., \& Rossier, J. (2015). Professional trajectories, individual characteristics, and staying satisfied and healthy. Journal of Career Development. Advance online version. doi:10.1177/0894845315584161

Kenny, M. E., Bledsoe, M. (2005). Contributions of the relation context to career adaptability among urban adolescents. Journal of Vocational Behaviour, 66, 257-272. doi:10.1016/j.jvb.2004.10.002

*Klehe, U.-C., Zikic, J., Van Vianen, A. E. M., \& De Pater, I. E. (2011). Career adaptability, turnover and loyalty during organizational downsizing. Journal of Vocational Behavior, 79, 217-229. doi:10.1016/j.jvb.2011.01.004

*Koen, J., Klehe, U. C., Van Vianen, A. E., Zikic, J., \& Nauta, A. (2010). Job-search strategies and reemployment quality: The impact of career adaptability. Journal of Vocational Behavior, 77, 126-139. doi:10.1016/j.jvb.2010.02.004 
*Koen, J., Klehe, U. C., \& Van Vianen, A. E. (2012). Training career adaptability to facilitate a successful school-to-work transition. Journal of Vocational Behavior, 81, 395-408. doi: 10.1016/j.jvb.2012.10.003

*Konstam, V., Celen-Demirtas, S., Tomek, S., \& Sweeney, K. (2015). Career adaptability and subjective well-being in unemployed emerging adults: A promising and cautionary tale. Journal of Career Development. Advance online publication. doi:10.1177/0894845315575151

Lazarus, R. S. (1999). Stress and emotion: A new synthesis. New York, NY: Springer.

Lazarus, R. S., \& Folkman, S. (1984). Stress, appraisal, and coping. New York, NY: Springer.

Lent, R. W. (2005). A social cognitive view of career development and counselling . In Brown, S. D., \& Lent, R. W. (Eds.). Career development and counseling: Putting theory and research to work (pp. 101-127). Hoboken, NJ: Wiley.

*Leong, F. T., \& Ott-Holland, C. (2014). Career adaptability: Theory and measurement. In D. Chan (Ed.). Individual Adaptability to Changes at Work: New Directions in Research (pp. 95-114). New York, NY: Routledge

Leong, F. T., \& Walsh, B. (2012). Guest editor's introduction to the special issue. Journal of Vocational Behavor, 80, 705-711. doi:10.1016/j.jvb.2012.03.003

*Li, Y., Guan, Y., Wang, F., Zhou, X., Guo, K., Jiang, P., Mo, Z., Li, Y., \& Fang, Z. (2015). Big five personality and BIS/BAS traits as predictors of career explorations: The mediation role of career adaptability. Journal of Vocational Behavior, 89, 39-45. doi:10.1016/j.jvb.2015.04.006

*Maggiori, C., Johnston, C. S., Krings, F., Massoudi, K., \& Rossier, J. (2013). The role of career adaptability and work conditions on general and professional well-being. Journal of Vocational Behavior, 83, 437-449. doi:10.1016/j.jvb.2013.07.001 
*Maggiori, C., Rossier, J., \& Savickas, M. (2015). Career Adapt-Abilities Scale-Short Form (CAAS-SF): Construction and validation. Journal of Career Assessment. Advance online publication. doi:10.1177/1069072714565856

*Maree, J. G, \& Gerruty, E. W. (2014). Narrative counselling with a young engineer. Journal of psychology in Africa, 24(5), 457-463

McArdle, S., Waters, L., Briscoe, J. P., \& Hall, D. T. (Tim). (2007). Employability during unemployment: Adaptability, career identity and human and social capital. Journal of Vocational Behavior, 71, 247-264. doi:10.1016/j.jvb.2007.06.003

McIlveen, P., Beccaria, G., Burton, L. J. (2013). Beyond conscientiousness: Career optimism and satisfaction with academic major. Journal of Vocational Behavior, 83, 229-236. doi:10.1016/j.jvb.2013.05.005

*McMahon, M., Watson, M., \& Bimrose, J. (2012). Career adaptability: A qualitative understanding from the stories of older women. Journal of Vocational Behavior, 80, 762-768. doi:10.1016/j.jvb.2012.01.016

Mischel, W. (2009). From personality and assessment (1968) to personality science, 2009. Journal of Research in Personality, 43, 282-290. doi:10.1016/j.jrp.2008.12.037

Mischel, W., \& Shoda, Y. (1995). A cognitive-affective system theory of personality: Reconceptualizing situations, dispositions, dynamics, and invariance in personality structure. Psychological Review, 102, 246-268. doi:10.1037/0033-295X.102.2.246

*Negru-Subtirica, O., \& Pop, E. I., \& Crocetti, E. (2015). Developmental trajectories and reciprocal associations between career adaptability and vocational identity: A threewave longitudinal study with adolescents. Journal of Vocational Behavior, 88, 131142. doi:10.1016/j.jvb.2015.03.004

*Nota, L., Ginevra, M. C., Soresi, S. (2012). The career and work adaptability questionnaire (CWAQ): A first contribution to its validation. Journal of Adolescence, 35, $1557-$ 1569. doi:10.1016/j.adolescence.2012.06.004 
O'Connell, D. J., McNeely, E., \& Hall, D. T. (2008). Unpacking personal adaptability at work. Journal of Leadership \& Organizational Studies, 14, 248-259. doi:10.1177/1071791907311005

*Ohme, M., \& Zacher, H. (2015). Job performance ratings: The relative importance of mental ability, conscientiousness, \& career adaptability. Journal of Vocational Behavior, 87, 161-170. doi:10.1016/j.jvb.2015.01.003

*Öncel, L. (2014). Career Adapt-Abilities Scale: Convergent validity of subscale scores. Journal of Vocational Behavior, 85, 13-17. doi:10.1016/j.jvb.2014.03.006

*Omar, S., \& Noordin, F. (2013). Career adaptability and intention to leave among ICT professionals: An exploratory study. TOJET, 12, 11-18

Ployhart, R., \& Bliese, P. (2006). Individual adaptability (I-ADAPT) theory: Conceptualizing the antecedents, consequences, and measurement of individual differences in adaptability. Advances in Human Performance and Cognitive Engineering Research, $6,3-39$.

*Praskova, A., Creed, P. A., \& Hood, M. (2013). Facilitating engagement in new career goals: the moderating effects of personal resources and career actions. International Journal for Educational and Vocational Guidance, 13, 115-134. doi:10.1007/s10775-013$9242-2$

*Praskova, A., Hood, M. \& Creed, P. A. (2014). Testing a calling model of psychological career success in Australian young adults: A longitudinal study. Journal of Vocational Behavior, 85, 125-135. doi:10.1016/j.jvb.2014.04.004

*Porfeli, E. J., \& Savickas, M. L. (2012). Career Adapt-Abilities Scale-USA Form: Psychometric properties and relation to vocational identity. Journal of Vocational Behavior, 80, 748-753. doi: 10.1016/j.jvb.2012.01.009 
*Pouyaud, J., Vignoli, E., Dosnon, O., \& Lallemand, N. (2012). Career adapt-abilities scaleFrance form: Psychometric properties and relationships to anxiety and motivation. Journal of Vocational Behavior, 80, 692-697. doi:10.1016/j.jvb.2012.01.021

Pulakos, E. D., Arad, S., Donovan, M. A., \& Plamondon, K. E. (2000). Adaptability in the workplace: development of a taxonomy of adaptive performance. Journal of Applied Psychology, 85, 612-624. doi:10.1037/0021-9010.85.4.612

Reise, S. P. (2012). The rediscovery of bifactor measurement models. Multivariate Behavioral Research, 47, 667-696. doi:10.1080/00273171.2012.715555

*Rocha, M. (2012). Transferable skills representations in a Portuguese college sample: gender, age, adaptability and vocational development. European Journal of Psychology of Education, 27, 77-90. doi:10.1007/s10212-011-0067-4

*Rocha, M. (2015). Predictors of the acquisition and portability of transferable skills: a longitudinal Portuguese case study on education. Higher Education, 69, 607-624. doi: $10.1007 / \mathrm{s} 10734-014-9793-2$

Rossier, J. (2015a) Career adaptability and life designing. In L. Nota \& J. Rossier (Eds.), Handbook of the life design paradigm: From practice to theory, from theory to practice (pp. 153-168). Göttingen, Germany: Hogrefe.

Rossier J. (2015b). Personality assessment and career interventions. In P. J. Hartung, M. L. Savickas, \& W. B. Walsh (Eds.), APA handbook of career intervention: Foundations (Vol. 1) (pp. 327-350). . Washington, DC: American Psychological Association.

*Rossier, J., Zecca, G., Stauffer, S. D., Maggiori, C., \& Dauwalder, J. P. (2012). Career adapt-abilities scale in a French-speaking Swiss sample: Psychometric properties and relationships to personality and work engagement. Journal of Vocational Behavior, 80, 734-743. doi:10.1016/j.jvb.2012.01.004 
*Rottinghaus, P. J., Buelow, K. L., Matyja, A. (2012). The career futures inventory-revised: Measuring dimensions of career adaptability. Jouranl of Career Assesment, 20, 123 139. doi:10.1177/1069072711420849

*Rottinghaus, P. J, Day, S. X. Borgen, F. H (2005). The Career Futures Inventory: A measure of Career-Related Adaptability and Optimism. Journal of Career Assessment, 13, 324. doi: $10.1177 / 1069072704270271$

*Rusu, A., Mairean, C., Hojbota, A., Gheramis, L R., Gavriloaiei (2015). Relationships of career adapt-abilities with explicit and implicit self-concepts. Journal of Vocational Behavior, 89, 92-101. doi:10.1016/j.jvb.2015.05.003

*Santilli, S., Nota, L., Ginevra, M. C., \& Soresi, S. (2014). Career adaptability, hope and life satisfaction in workers with intellectual disability. Journal of Vocational Behavior, 85, 67-74. doi:10.1016/j.jvb.2014.02.011

*Savickas, M. L. (1997). Career adaptability: An integrative construct for life-span, life-space theory. The Career Development Quarterly, 45, 247-259. doi:10.1002/j.21610045.1997.tb00469.x

*Savickas, M. L. (2002). Career construction: A developmental theory of vocational behavior. In D. Brown (Ed.), Career choice and development (pp. 149-205). San Francisco, CA: Jossey-Bass.

*Savickas, M. L. (2005). The theory and practice of career construction. In S. D. Brown \& R. W. Lent (Eds.), Career development and counseling: Putting theory and research to work (pp. 42-70). Hoboken, NJ: Wiley.

*Savickas, M. L. (2009). Life-design International Research Group: Career Adaptability Project Meeting. Meeting Report, Berlin July 19, Humboldt Universität.

*Savickas, M. L., \& Porfeli, E. J. (2011). Revision of the Career Maturity Inventory: The Adaptability Form. Journal of Career Assesment, 19, 355-374. doi:

$10.1177 / 1069072711409342$ 
*Savickas, M. L., \& Porfeli, E. J. (2012). Career Adapt-Abilities Scale: Construction, reliability, and measurement equivalence across 13 countries. Journal of Vocational Behavior, 80, 661-673. doi:10.1016/j.jvb.2012.01.011

*Savickas, M. L. (2013). Career construction theory and practice. Career development and counseling: Putting theory and research to work ( $2^{\text {nd }}$ ed.) (pp. 147-183). Hoboken, NJ: Wiley.

*Scholl, M. B., \& Cascone, J. (2010). The constructivist resume: Promoting the Career Adaptability of Graduate Students in Counselling Programs. The Career Development Quarterly, 59, 180-191. Doi:10.1002/j.2161-0045.2010.tb00061.x

Shoda, Y., LeeTiernan, S., \& Mischel, W. (2002). Personality as a dynamical system: Emergence of stability and distinctiveness from intra- and interpersonal interactions. Personality and Social Psychology Review, 6, 316-325. doi:10.1207/S15327957PSPR0604_06

*Shulman, S., Vasalampi, K., Barr, Z., Livne, Y., Nurmi, J. E., Pratt, M. W. (2014). Typologies and precursors of career adaptability patterns among emerging adults: A seven-year longitudinal study. Journal of Adolescence, 37, 1505-1515. doi:10.1016/j.adolescence.2014.06.003

*Soresi, S., Nota, L., \& Ferrari, L. (2012). Career adapt-abilities scale-Italian form: Psychometric properties and relationships to breadth of interests, quality of life, and perceived barriers. Journal of Vocational Behavior, 80, 705-711. doi:10.1016/j.jvb.2012.01.020

*Soresi, S., Nota, L., Ferrari, L., \& Ginevra, M. C. (2014). Parental Influences on Youth's Career Construction. In G. Arulmani, A. J. Bakshi, Leong, F. T., \& A. G. Watts (Eds.). Handbook of Career Development (pp. 149-172). NewYork, NY: Springer.

*Spurk, D., \& Kauffeld, S., Meinecke, A. L., \& Ebner, K. (2015). Why do adaptable people feel less insecure? Indirect effects of career adaptability on job and career insecurity 
CAREER ADAPTABILITY REVIEW

via two types of perceived marketability. Journal of Career Assessment. Advance online publication. doi:10.1177/1069072715580415

*Stauffer, S. D., Maggiori, C., Froidevaux, A., \& Rossier, J. (2014). Adaptability in action: Using personality, aptitude, and interest data to help clients increase their emotional, social, and cognitive career meta-capacities. In M. Coetzer (Ed.), Perspectives on psycho-social career meta-capacities (p. 55-74). New York, NY: Springer.

Stawski, R. S., Sliwinski, M. J., Almeida, D. M., \& Smyth, J. M. (2008). Reported exposure and emotional reactivity to daily stressors: The roles of adult age and global perceived stress. Psychology and Aging, 23, 52-61. doi:10.1037/0882-7974.23.1.52

*Stoltz, K. B., Wolff, L. A., Monroe, A. E., Farris, H. R., \& Mzahreh, L. G. (2013). Adlerian lifestlye, stress coping, and career adaptability: Relationships and dimensions. Career Development Quarterly, 61, 194-209. doi:10.1002/j.2161-0045.2013.00049.x

*Stringer, K., Kerpelman, J., \& Skorikov, V. (2011). Career preparations: A longitudinal, process-oriented examination. Journal of Vocational Behavior, 79, 158-169. doi:10.1016/j.jvb.2010.12.012

Sullivan, S. E., \& Baruch, Y. (2009). Advances in career theory and research: A critical review and agenda for future exploration. Journal of Management, 35, 1542-1571. Doi: $10.1177 / 0149206309350082$

Super, D. E., \& Knasel, E. G. (1981). Career development in adulthood: Some theoretical problems and a possible solution. British Journal of Guidance \&Counselling, 9, 194201. doi:10.1080/03069888108258214

*Taber, B. J., \& Blankemeyer, M. (2014). Future work self and career adaptability in the prediction of proactive career behaviors. Journal of Vocational Behavior, 86, 20-27. doi:10.1016/j.jvb.2014.10.005

*Teixeira, M. A. P., Bardagi, M. P., Lassance, M. C. P., Magalhães, M. D. O., \& Duarte, M. E. (2012). Career adapt-abilities scale—Brazilian form: psychometric properties and 
CAREER ADAPTABILITY REVIEW

relationships to personality. Journal of Vocational Behavior, 80, 680-685.

doi:10.1016/j.jvb.2012.01.007

*Tian, Y., \& Fan, X. (2014). Adversity quotients, environmental variables and career adaptability in student nurses. Journal of Vocational Behavior, 85, 251-257. doi:10.1016/j.jvb.2014.07.006

*Tien, H. L. S., Lin, S. H., Hsieh, P. J., \& Jin, S. R. (2014). The Career Adapt-Abilities Scale in Macau: Psychometric characteristics and construct validity. Journal of Vocational Behavior, 84, 259-265. doi:10.1016/j.jvb.2014.01.005

*Tolentino, L. R., Garcia, P. R. J. M., Restubog, S. L. D., Bordia, P., \& Tang, R. L. (2013). Validation of the Career Adapt-Abilities Scale and an examination of a model of career adaptation in the Philippine context. Journal of Vocational Behavior, 83, 410418. doi:10.1016/j.jvb.2013.06.013

*Tolentino, L. R., Garcia, P. R. J. M., Lu, V. N., Restubog, S. L. D., Bordia, P., \& Plewa, C. (2014a). Career adaptation: The relation of adaptability to goal orientation, proactive personality, and career optimism. Journal of Vocational Behavior, 84, 39-48. doi:10.1016/j.jvb.2013.11.004

*Tolentino, L. R., Sedoglavich, V., Lu, V. N., Garcia, P. R. J. M., \& Restubog, S. L. D. (2014b). The role of career adaptability in predicting entrepreneurial intentions: A moderated mediation model. Journal of Vocational Behavior, 85, 403-412. doi:10.1016/j.jvb.2014.09.002

*Urbanaviciute, I., Kairys, A., Pociute, B., \& Liniauskaite, A. (2014). Career Adaptability in Lithuania: A Test of Psychometric Properties and a Theoretical Model. Journal of Vocational Behavior, 85, 433-442. doi: 10.1016/j.jvb.2014.09.005

*Uy, M. A (2014). Proactivity, adaptability and boundaryless career attitudes: The mediating role of entrepreneurial alertness. Journal of Vocational Behavior, 86, 115-123. doi:10.1016/j.jvb.2014.11.005 
Vander Elst, T., Van den Broeck, A., De Cuyper, N., \& De Witte, H. (2014). On the reciprocal relationship between job insecurity and employee well-being: Mediation by perceived control? Journal of Occupational and Organizational Psychology, 87, 671693. doi:10.1111/joop. 12068

*Van Vianen, A. E. M., De Pater, I., \& Preenan, P. T. (2009). Adaptable career: Maximizing less and exploring more. The Career Development Quarterly, 57, 298-309. doi: 10.1002/j.2161-0045.2009.tb00115.x

*Van Vianen, A. E. M., Klehe, U.-C., Koen, J., \& Dries, N. (2012). Career adapt-abilities scale - Netherlands form: Psychometric properties and relationships to ability, personality, and regulatory focus. Journal of Vocational Behavior, 80, 716-724. doi:10.1016/j.jvb.2012.01.002

*Vilhjálmsdóttir, G., Kjartansdóttir, G. B., Smáradóttir, S. B., \& Einarsdóttir, S. (2012). Career adapt-abilities scale-Icelandic form: Psychometric properties and construct validity. Journal of Vocational Behavior, 80, 698-704. doi:10.1016/j.jvb.2012.01.013

*Whiston. S. C., Feldwisch, R. P., Evans, K. M., Blackman, C. S., \& Gilman, L. (2015). Older professional women's views on work: A qualitative analysis. The Career Development Quarterly, 63, 98-112. doi:10.1002/cdq.12007

*Wilkins, K. G., Santilli, S., Ferrari, L., Nota, L., Tracey, T. J., \& Soresi, S. (2014). The relationship among positive emotional dispositions, career adaptability, and satisfaction in Italian high school students. Journal of Vocational Behavior, 85, 329338. doi:10.1016/j.jvb.2014.08.004

*Yang, W., Guan, Y., Lai, X., She, Z., \& Lockwood, A. J. (2015). Career adaptability and perceived overqualification: Testing a dual-path model among Chinese human resource management professionals. Journal of Vocational Behavior. Advance online version. doi:10.1016/j.jvb.2015.08.007 
*Yousefi, Z., Abedi, M., Baghban, I., Eatemadi, O., \& Abedi, A. (2011). Personal and situational variables, and career concerns: Predicting career adaptability in young adults. The Spanish Journal of Psychology, 14, 263-271.

doi:10.5209/rev_SJOP.2011.v14.n1.23

*Zacher, H. (2014a). Career adaptability predicts subjective career success above and beyond personality traits and core self-evaluations. Journal of Vocational Behavior, 84, 21-30. doi:10.1016/j.jvb.2013.10.002

*Zacher, H. (2014b). Individual difference predictors of change in career adaptability over time. Journal of Vocational Behavior, 84, 188-198. doi:10.1016/j.jvb.2014.01.001

*Zacher, H. (2015). Daily manifestations of career adaptability: Relationships with job and career outcomes. Journal of Vocational Behavior. Advance online version. doi:10.1016/j.jvb.2015.09.003

*Zacher, H. \& Griffin, B. (2015). Older Workers' Age as a moderator of the relationship between career adaptability and job satisfaction. Work, Aging, \& Retirement. Advance online publication. doi:10.1093/workar/wau009

*Zacher, H., \& Ambiel. R., \& Noronha, A. P. P. (2015). Career adaptability and career entrenchment. Journal of Vocational Behavior, 88, 164-173. doi:10.1016/j.jvb.2015.03.006

*Zikic, J., \& Klehe, U.-C. (2006). Job loss as a blessing in disguise: The role of career exploration and career planning in predicting reemployment quality. Journal of Vocational Behavior, 69, 391-409. doi:10.1016/j.jvb.2006.05.007 
Table 1. Constructs included in the career adaptability research mapped onto the main aspects of the conceptual framework

\begin{tabular}{|c|c|c|c|}
\hline Adaptive readiness & $\begin{array}{l}\text { Adaptability } \\
\text { resources }\end{array}$ & Adapting responses & Adaptation results \\
\hline $\begin{array}{l}\text { Tenacious goal } \\
\text { pursuit }\end{array}$ & Concern & Career planning & Career satisfaction \\
\hline $\begin{array}{l}\text { Flexible goal } \\
\text { adjustment }\end{array}$ & Control & $\begin{array}{l}\text { Career decision- } \\
\text { making difficulties }\end{array}$ & Promotability \\
\hline $\begin{array}{l}\text { Learning goal } \\
\text { orientation }\end{array}$ & Curiosity & Career exploration & $\begin{array}{l}\text { Entrepreneurial } \\
\text { intentions }\end{array}$ \\
\hline Proactive personality & Confidence & $\begin{array}{l}\text { Occupational self- } \\
\text { efficacy }\end{array}$ & $\begin{array}{l}\text { Organizational } \\
\text { loyalty }\end{array}$ \\
\hline Career optimism & & $\begin{array}{l}\text { Entrepreneurial self- } \\
\text { efficacy }\end{array}$ & Turnover \\
\hline Core self-evaluations & & $\begin{array}{l}\text { Career decision- } \\
\text { making self-efficacy }\end{array}$ & $\begin{array}{l}\text { Academic } \\
\text { satisfaction }\end{array}$ \\
\hline Proactivity & & $\begin{array}{l}\text { Proactive skill } \\
\text { development }\end{array}$ & Employment status \\
\hline Hope & & $\begin{array}{l}\text { Proactive } \\
\text { networking } \\
\text { behaviours }\end{array}$ & \\
\hline Future Work Self & & & \\
\hline
\end{tabular}


Table 2. Overview of measures that have been used to measure career adaptability resources and responses

\begin{tabular}{|c|c|c|c|}
\hline Name & Reference & Sub-Dimensions & Number of Items \\
\hline Career Adapt- & Savickas \& Porfeli & Concern & 24 \\
\hline Abilities Scale & 2012 & $\begin{array}{l}\text { Control } \\
\text { Curiosity } \\
\text { Confidence }\end{array}$ & \\
\hline Career Adap- & Maggiori, Rossier, \& & Concern & 12 \\
\hline $\begin{array}{l}\text { Abilities Scale - } \\
\text { Short Form }\end{array}$ & Savickas, 2015 & $\begin{array}{l}\text { Control } \\
\text { Curiosity } \\
\text { Confidence }\end{array}$ & \\
\hline Career and Work & Nota, Ginevra, \& & Concern & 50 \\
\hline Adaptability & Soresi, 2012 & Control & \\
\hline Questionnaire & & $\begin{array}{l}\text { Curiosity } \\
\text { Confidence }\end{array}$ & \\
\hline $\begin{array}{l}\text { Career Maturity } \\
\text { Inventory - Form C }\end{array}$ & $\begin{array}{l}\text { Savickas \& Porfeli, } \\
2011\end{array}$ & $\begin{array}{l}\text { Career choice } \\
\text { readiness } \\
\text { Concern } \\
\text { Curiosity } \\
\text { Confidence } \\
\text { Consultation }\end{array}$ & 24 \\
\hline $\begin{array}{l}\text { Career Adaptability } \\
\text { Inventory }\end{array}$ & $\begin{array}{l}\text { In Ferrerira \& } \\
\text { Coetzee; Ferreira, } \\
\text { Coetzee, \& } \\
\text { Masenge, } 2013\end{array}$ & $\begin{array}{l}\text { Concern } \\
\text { Control } \\
\text { Curiosity } \\
\text { Confidence } \\
\text { Cooperation }\end{array}$ & 55 \\
\hline $\begin{array}{l}\text { Student's Career } \\
\text { Construction } \\
\text { Inventory }\end{array}$ & Savickas, 2009 & $\begin{array}{l}\text { Concern } \\
\text { Control } \\
\text { Curiosity } \\
\text { Confidence } \\
\text { Cooperation }\end{array}$ & 25 \\
\hline $\begin{array}{l}\text { Career Futures } \\
\text { Inventory }\end{array}$ & $\begin{array}{l}\text { Rottinghaus et al., } \\
2005\end{array}$ & $\begin{array}{l}\text { Career Adaptability } \\
\text { Career Optimism } \\
\text { Perceived } \\
\text { Knowledge }\end{array}$ & 25 \\
\hline I-Adapt Scale & $\begin{array}{l}\text { Ployhart \& Bliese, } \\
2006\end{array}$ & $\begin{array}{l}\text { Culture } \\
\text { Uncertainty } \\
\text { Physical } \\
\text { Interpersonal } \\
\text { Learning } \\
\text { Work stress } \\
\text { Creativity } \\
\text { Crisis }\end{array}$ & 55 \\
\hline
\end{tabular}


Table 3. Predictors and outcomes of adaptability resources and adaptability responses

\begin{tabular}{|c|c|c|c|c|c|}
\hline \multicolumn{3}{|c|}{ Adaptability resources } & \multicolumn{3}{|c|}{ Adaptability responses } \\
\hline Correlates & Predictors & Outcomes & Correlates & Predictors & Outcomes \\
\hline $\begin{array}{l}\text { Conscientiousn } \\
\text { ess }\end{array}$ & $\begin{array}{l}\text { Hope and } \\
\text { optimism }\end{array}$ & $\begin{array}{l}\text { Life } \\
\text { satisfaction* }\end{array}$ & $\begin{array}{l}\text { Intrinsic } \\
\text { religiousne } \\
\text { ss }\end{array}$ & $\begin{array}{l}\text { Social } \\
\text { support* }\end{array}$ & $\begin{array}{l}\text { Career } \\
\text { aspirations* }\end{array}$ \\
\hline Extraversion & $\begin{array}{l}\text { Low } \\
\text { tolerance for } \\
\text { unpredictabili } \\
\text { ty }\end{array}$ & $\begin{array}{l}\text { Positive } \\
\text { affect* }\end{array}$ & $\begin{array}{l}\text { Spiritual } \\
\text { awareness }\end{array}$ & $\begin{array}{l}\text { Non- } \\
\text { immigrant } \\
\text { background } \\
*\end{array}$ & $\begin{array}{l}\text { Career } \\
\text { loyalty* }\end{array}$ \\
\hline Agreeableness & $\begin{array}{l}\text { Sense of } \\
\text { control }\end{array}$ & $\begin{array}{l}\text { Negative } \\
\text { affect* }\end{array}$ & & $\begin{array}{l}\text { Positive } \\
\text { emotional } \\
\text { disposition } \\
*\end{array}$ & Turnover* \\
\hline Openness & $\begin{array}{l}\text { Emotional } \\
\text { Intelligence }\end{array}$ & $\begin{array}{l}\text { Self-rated } \\
\text { health* }\end{array}$ & & $\begin{array}{l}\text { Continuing } \\
\text { vocational } \\
\text { education* }\end{array}$ & $\begin{array}{l}\text { Organization } \\
\text { al loyalty* }\end{array}$ \\
\hline Neuroticism & $\begin{array}{l}\text { Future work } \\
\text { self }\end{array}$ & $\begin{array}{l}\text { Job } \\
\text { satisfaction* }\end{array}$ & & $\begin{array}{l}\text { Internship } \\
\text { quality }\end{array}$ & $\begin{array}{l}\text { Sense of } \\
\text { power* }\end{array}$ \\
\hline anxiety & $\begin{array}{l}\text { Core self- } \\
\text { evaluations }\end{array}$ & $\begin{array}{l}\text { Job search } \\
\text { self-efficacy* }\end{array}$ & & Hope & $\begin{array}{l}\text { Life } \\
\text { satisfaction* }\end{array}$ \\
\hline Self-esteem & $\begin{array}{l}\text { Proactivity } \\
\text { and proactive } \\
\text { personality }\end{array}$ & $\begin{array}{l}\text { Career } \\
\text { planning* }\end{array}$ & & $\begin{array}{l}\text { Learning } \\
\text { orientation }\end{array}$ & $\begin{array}{l}\text { Re- } \\
\text { employment } \\
\text { quality* }\end{array}$ \\
\hline $\begin{array}{l}\text { Individual } \\
\text { adaptability }\end{array}$ & $\begin{array}{l}\text { Positive } \\
\text { relationships } \\
\text { with parents }\end{array}$ & $\begin{array}{l}\text { Career } \\
\text { decision } \\
\text { making } \\
\text { difficulties* }\end{array}$ & & $\begin{array}{l}\text { Career } \\
\text { concerns }\end{array}$ & $\begin{array}{l}\text { Job search } \\
\text { behaviours* }\end{array}$ \\
\hline Meaningfulness & $\begin{array}{l}\text { Social } \\
\text { support }\end{array}$ & $\begin{array}{l}\text { Career } \\
\text { exploration* }\end{array}$ & & $\begin{array}{l}\text { Performanc } \\
\text { e-prove } \\
\text { orientation }\end{array}$ & $\begin{array}{l}\text { Career } \\
\text { counselling* }\end{array}$ \\
\hline $\begin{array}{l}\text { Promotion } \\
\text { Regulatory } \\
\text { focus }\end{array}$ & $\begin{array}{l}\text { Career } \\
\text { specific } \\
\text { parental } \\
\text { behaviours }\end{array}$ & $\begin{array}{l}\text { Occupational } \\
\text { self-efficacy* }\end{array}$ & & $\begin{array}{l}\text { Redundanc } \\
\mathrm{y}^{*}\end{array}$ & \\
\hline $\begin{array}{l}\text { Prevention } \\
\text { regulatory focus }\end{array}$ & $\begin{array}{l}\text { Unemployme } \\
\text { nt }\end{array}$ & $\begin{array}{l}\text { Vocational } \\
\text { exploration* }\end{array}$ & & $\begin{array}{l}\text { Job } \\
\text { Insecurity* }\end{array}$ & \\
\hline Motivation & $\begin{array}{l}\text { Learning } \\
\text { environment }\end{array}$ & $\begin{array}{l}\text { Vocational } \\
\text { commitment } \\
*\end{array}$ & & & \\
\hline $\begin{array}{l}\text { Tenacious goal } \\
\text { pursuit }\end{array}$ & Age* & $\begin{array}{l}\text { Identification } \\
\text { with } \\
\text { commitment } \\
*\end{array}$ & & & \\
\hline $\begin{array}{l}\text { Perceived } \\
\text { barriers } \\
\text { Flexible goal } \\
\text { adjustment }\end{array}$ & $\begin{array}{l}\text { Temporal } \\
\text { focus* } \\
\text { Education* }\end{array}$ & $\begin{array}{l}\text { Entrepreuneri } \\
\text { al intentions* } \\
\text { Quality of } \\
\text { life }\end{array}$ & & & \\
\hline
\end{tabular}




\begin{tabular}{|c|c|c|}
\hline $\begin{array}{l}\text { Response to } \\
\text { adversity }\end{array}$ & $\begin{array}{l}\text { Extraversion } \\
*\end{array}$ & Work stress \\
\hline $\begin{array}{l}\text { Vocational } \\
\text { identity status }\end{array}$ & Neuroticism* & $\begin{array}{l}\text { Intentions to } \\
\text { leave }\end{array}$ \\
\hline Employability & $\begin{array}{l}\text { Core self- } \\
\text { evaluations* }\end{array}$ & Job-Fit \\
\hline $\begin{array}{l}\text { Career } \\
\text { satisfaction }\end{array}$ & Openness* & $\begin{array}{l}\text { Career } \\
\text { entrenchment }\end{array}$ \\
\hline Promotability & $\begin{array}{l}\text { Vocational } \\
\text { commitment* }\end{array}$ & $\begin{array}{l}\text { Career } \\
\text { satisfaction }\end{array}$ \\
\hline $\begin{array}{l}\text { Boundaryless } \\
\text { mindset }\end{array}$ & Self-Doubt* & $\begin{array}{l}\text { Self-rated } \\
\text { performance }\end{array}$ \\
\hline $\begin{array}{l}\text { Protean career } \\
\text { orientation }\end{array}$ & $\begin{array}{l}\text { Learning goal } \\
\text { orientation* }\end{array}$ & $\begin{array}{l}\text { Task } \\
\text { performance }\end{array}$ \\
\hline $\begin{array}{l}\text { Professional } \\
\text { competences }\end{array}$ & $\begin{array}{l}\text { Proactive } \\
\text { personality* }\end{array}$ & $\begin{array}{l}\text { Career } \\
\text { performance }\end{array}$ \\
\hline calling & $\begin{array}{l}\text { Career } \\
\text { optimism* }\end{array}$ & $\begin{array}{l}\text { Organization } \\
\text { al retention } \\
\text { factors }\end{array}$ \\
\hline $\begin{array}{c}\text { Transferrable } \\
\text { skills }\end{array}$ & Self-Esteem* & $\begin{array}{l}\text { Academic } \\
\text { satisfaction }\end{array}$ \\
\hline $\begin{array}{l}\text { Career } \\
\text { aspirations } \\
\text { Frequency of } \\
\text { career } \\
\text { exploration } \\
\text { behaviours } \\
\text { Career } \\
\text { decidedness }\end{array}$ & $\begin{array}{l}\text { Career } \\
\text { calling* }\end{array}$ & $\begin{array}{l}\text { Salary } \\
\text { satisfaction } \\
\text { Career } \\
\text { decidedness }\end{array}$ \\
\hline
\end{tabular}


Appendix 1. Sample items from the different career adaptability measures

\section{CAAS and CAAS SF}

Concern: Thinking about what my future will be like

Control: Taking responsibility for my actions

Curiosity: Looking for opportunities to grow as a person

Confidence: Taking care to do things well

\section{Career and Work Adaptability Questionnaire}

Confidence: I am confident in my abilities to take good decisions

Control: Can control my nerves

Cooperation: Openly state my disagreement in the face of something wrong, injustice or abuse

Curiosity: Like exploring, fantasizing, imagining, thinking in an unconventional way, finding novel solutions.

Concern: I think about my future and try to predict it.

\section{Career Maturity Inventory - Form C}

Concern: There is no point in deciding on a job when the future is so uncertain $(\mathrm{R})$

Curiosity: I know very little about the requirements of jobs (R)

Confidence: There are so many things to consider in choosing an occupation, it is hard to make a decision

Consultation: Choosing a job is something that you do on your own (R)

\section{Career Adaptability Inventory}

Confidence: Remaining positive

Control: Relying on myself

Curiosity: Looking for opportunities to grow as a person

Concern: Becoming aware of the education and career choices that I must make

\section{Students' Career Construction Inventory}

Concern: Planning how to get into the occupation I chose

Control: Qualifying for the job that I like best.

Curiosity: Learning about different types of jobs

Confidence: Reassuring myself that I made a good occupational choice:

Cooperation: Discussing my career with teachers and advisors

\section{Career Future's Scale}

Career Adaptability: I can adapt to change in my career plans; I will adjust easily to shifting demands at work

Career Optimism: Thinking about my career inspires me; I am eager to pursue my career dreams

Perceived Knowledge: I am good at understanding job market trends; It is easy to see future job market trends

\section{I-Adapt Scale Example Items:}

Culture: I feel comfortable interacting with others who have different values and customs

Physical: I cannot work well when it is too hot or cold

Uncertainty: I can adjust my plans to changing conditions

Interpersonal: I try to be flexible when dealing with others

Learning: I am continually learning new skills for my job 
Work stress: I am usually stressed when I have a large work load Creativity: Ai am able to look at problems from a multitude of angles Crisis: I make excellent decision in times of crisis 